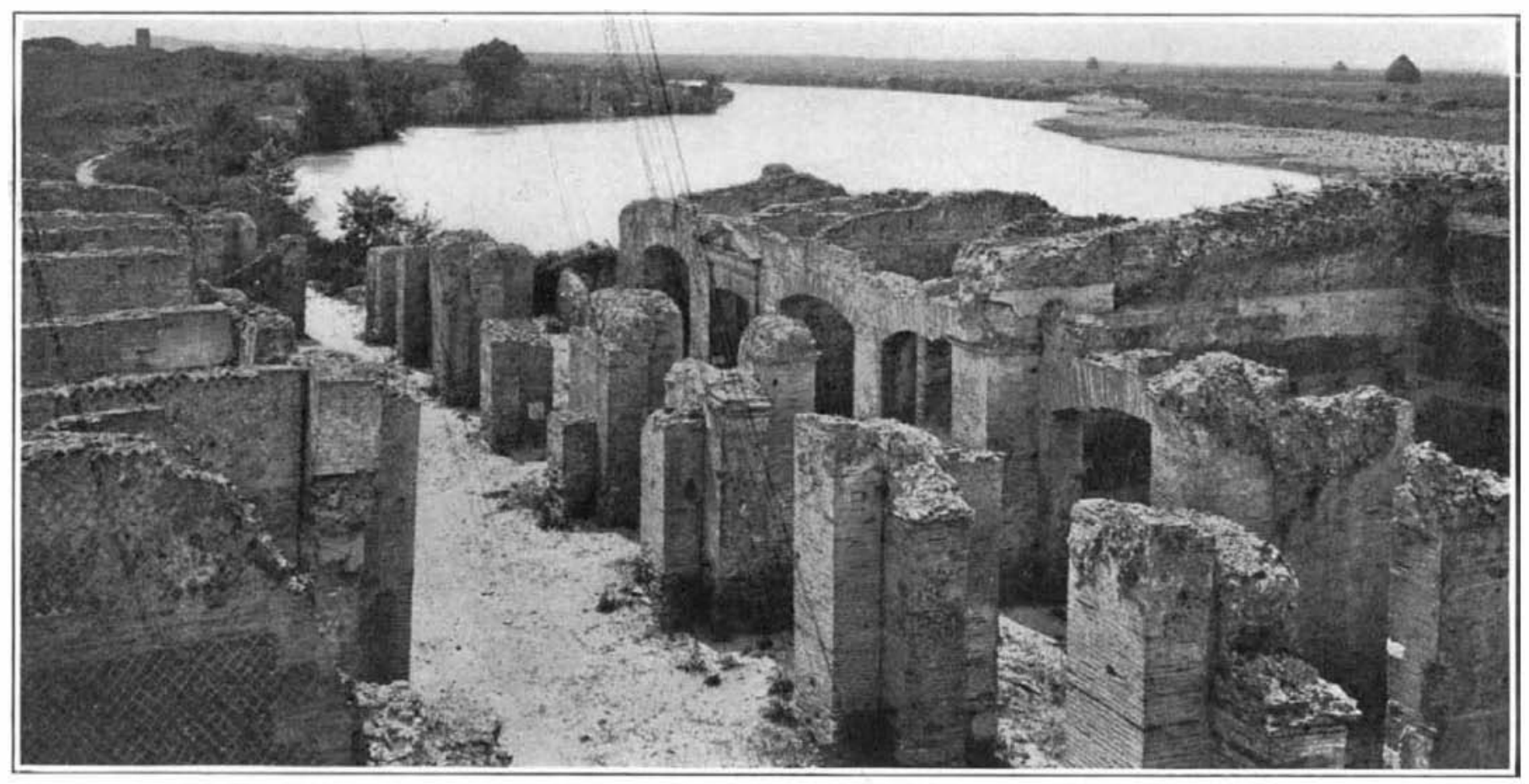

GENERAL VIEW OF ANCIENT OSTIA AND THE TIBER, SHOWING RUINS OF WAREHOUSES

\title{
A New Port for Rome
}

\section{The Ancient Harbors of Ostia and Porto on the Tiber}

\author{
By Albert A. Hopkins \\ Fellow of the American Geographical Society
}

$\mathrm{T}$ HE economic depression resulting from the World War has directed attention to the utilization of forgotten resources. We look to gain wealth from waterfalls and rapids, we try new foods and intensive cultivation, so it is not surprising to find Italy alert to save every lira by reclaiming her barren land and promoting housing in new localities.

Prince Orsini, of the famous Roman family, has succeeded in interesting capital in a scheme of land reclamation of the Agrum Romanum-an immense barren tract between Rome and the Mediterranean. This country was once of great fertility and was dotted with castles and villages but they fell a prey to marauders, Saracens and pirates, and then to the more deadly foe, malaria; for the region includes the famous Pontine Marshes. It is a mistake to consider this land as a dreary extent of stagnant, slimy water, traversed by melancholy roads; on the contrary the marshes resemble the rich plains of Lombardy with abundant grass and herbage which grow with a luxuriance which Italy of the North can never exhibit. No roads could be more excellent than those which lead through the marshes, upon which the carriage or automobile rolls along between unending alleys of trees whose thick branches afford a welcome shade from the scorching sun. Canals cross one another and drain off some of the water. Occasionally a solitary post house is passed which shows the effects of the poisonous effluvia which steam up from the marshes. The lime-washed walls are entirely covered with an unctuous gray-green mold. This stamp of corruption follows human beings as well and the peasants are pale yellow and sickly in the extreme.

It is now proposed to remedy all this, for the marshes can be drained and the country made one of the most healthful parts of Italy. This reclamation work will occupy six years and will cost $\$ 50,000,000$ - a large sum for Italy to invest at this juncture, but English and American banks have looked with favor on the project. Once the dread malaria is extir- pated, this land would be of inestimable value to Rome and would make the city self-supporting and bring back to the capital of the Casars something of its old time glory.

The chief town in the area is Ostia, which, in 50 B. C., was one of the principal cities of Italy, but in the first century it was ruined by the silting up of the port and without modern dredges the case was hopeless. The Emperor Claudius built a new harbor up the Tiber two miles above Ostia; this silted up in a time and the Emperor Trajan built another harbor in A. D. 103 united with the port of Claudius on the west and with the Tiber by a canal. In the 10th century this port became filled up and commerce went to mediaeval Ostia and in 1612 the canal of Trajan was once more cleared out by Pope Paul V. and connected with Fiumicino. Since then this has been the only way by which vessels can ascend the Tiber, the other branch having been almost entirely closed up by sand near its mouth. It is now proposed to build another city near Ostia to relieve the housing situation in Rome, the distance being less than twenty miles. This would give Rome a maritime port which she needs badly, Civita Vecchia being altogether too far away. The engineering charges would be borne in connection with the reclamation work on the marshes.

It would perhaps be worth the reader's while to glance briefly at a short sketch of Ostia, "Porto" as the ClaudianTrajan port is called, and also Porto d' Anzio the ancient Antium which was of great commercial and military importance to Rome. It should be noted that this seaport is not on the Tiber but is in the other direction about as far to the south of Ostia as Civita Vecchia is to the north.

The subject of the trade of Rome is an interesting and important one. The metropolis of the ancient world at one time numbered about $1,000,000$ inhabitants, and it was no small task to provision this city. Ostia, on the coast of the Mediterranean Sea, now about twenty-one miles by rail from Rome, was naturally the great entrepot. It was settled in the second century after the foundation of Rome, by Ancus 
Martius, and soon became an important commercial town. Under Augustus it lost some of its importance, due to the choking up of the harbor by the Tiber. Christianity was introduced at an early date, and the Bishopric of Ostia, according to some accounts, was founded by the apostles themselves. The early Popes were all consecrated by the Bishop of Ostia.

The Tiber at present washes down eight and one-half million tons of sand annually, and this gradual extension of the delta has left Ostia miles inland. The astronomer, Padre Secchi, and Professor Lanciani have determined that the average yearly advance of the coast is about 19 feet.

The Tiber was a bad river to navigate, and while an ancient man-of-war could easily get over the bar, owing to its light draught and great propelling power, merchantmen usually had to anchor outside and discharge their cargoes with the aid of lighters. The old Romans made no attempt to improve the harbor, which they could have done very easily, for vessels of 150 tons burden now reach Rome. In early times the vessels were towed upstream by oxen and buffaloes, tow-paths being provided for them. Navigation was not allowed at night and the vessels had to moor at stations. Professor Lanciani states that there were thirty of these stations between Rome and the sea. Vessels from Ostia often reached Alexandria in eleven days and Gibraltar in five days.

At Ostia the warehouses covered one-half of the town, which was two miles long and one mile wide. The city of Ostia must have presented a splendid appearance, as it contained fine temples, theaters, and villas of patricians, and the ruins were so extensive that for five centuries the villagers burned marble for lime without exhausting the supply; and when Poggio Bracciolini visited Ostia with Cosimo de' Medici they found the villagers occupied with burning an entire temple into lime. It is sad to contemplate the loss of so many antiquities, for the rude peasants burned wall facings and statues alike.

Our engraving represents the warehouses along the so- called "Street of Wharfs." The fioors are raised three feet above the pavement to facilitate the loading of carts. On the opposite side the ruins seem to belong to the private houses of merchants, the ground fioors and basements being used for storage purposes. One of the rooms is in excellent preservation. It is 36 feet long by 28 feet wide, with six rows of large earthen oil jars 4 feet in diameter, each marked with its capacity. Another store belonging to the same house is vaulted over and has two circular openings for light. The barrack of the firemen (vigles) and constables is one of the important ruins of Ostia. These men were numerous, as frays and fires are very apt to occur where large bodies of lawless sailors are congregated.

One of our engravings shows a portion of one of the warehouses, and it may also be seen in the middle of another of the engravings. It gives an admirable idea of the solidity with which the Romans built all constructions of this kind. Through the arch to the left may be seen the concrete which was faced with what is known as "opus recticulatum," where the stones were carefully cut so as to present a square or lozenge-shaped end, and are fitted very closely one to the other. These little blocks are about 3 inches square and are arranged to run in diagonal lines; the angles of the wall have neatly worked quoins with the inner end pointed so as to work in with the small lozenges. The effect of this sort of facing is very neat, but its beauty seems to have been very largely concesaled by stucco. The front walls of the warehouse were built of brick which average 1 foot 11 inches square. The voussoirs are also of brick and the pediment and entablature are admirably handled. The engraving is interesting as showing Roman methods of construction, and also as showing how well the Romans built, even where the structures were used for such ordinary purposes as warehouses.

The harbor which Claudius built two miles up the coast trom Ostia was inclosed by jetties. The area of the harbor was about 6,200,000 square feet, and the quays were over a

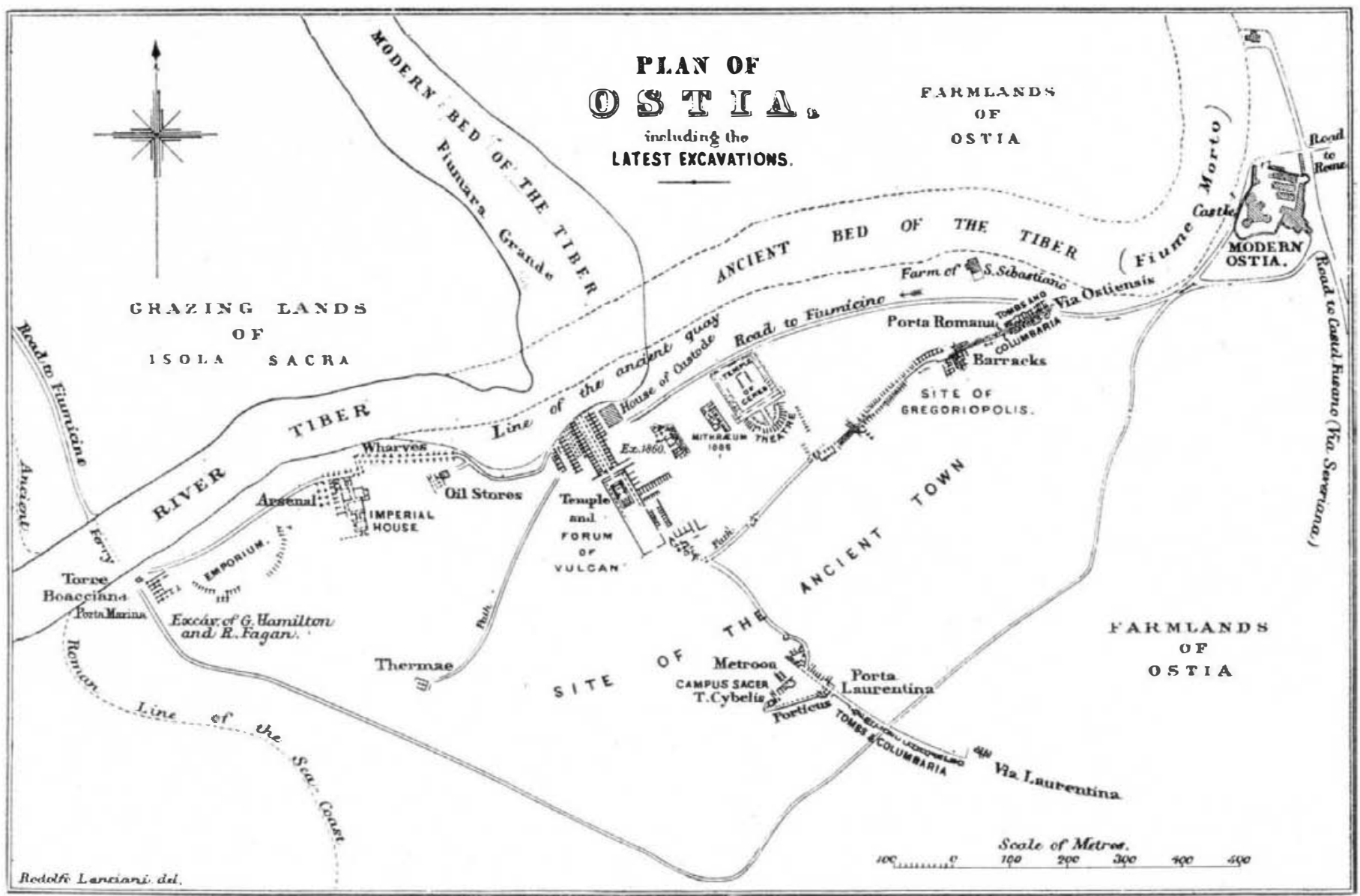

OSTIA, THE SEAPORT OF ANCIENT ROME, WHICH WAS SILTED UP BY THE TIBER 


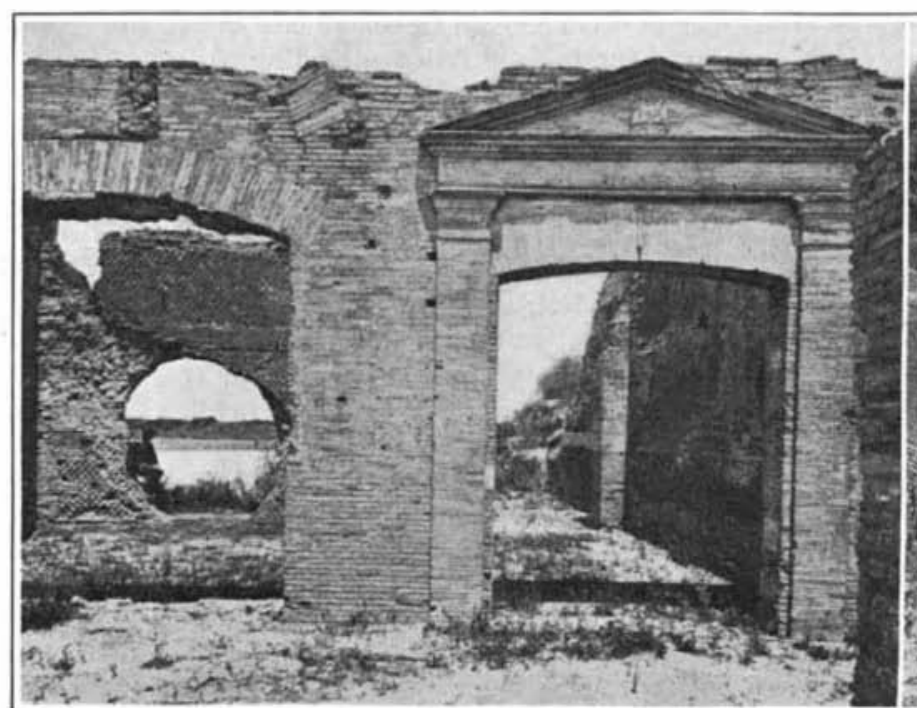

DOOR OF A MAGAZINE ON THE PRINCIPAL STREET OF OSTIA

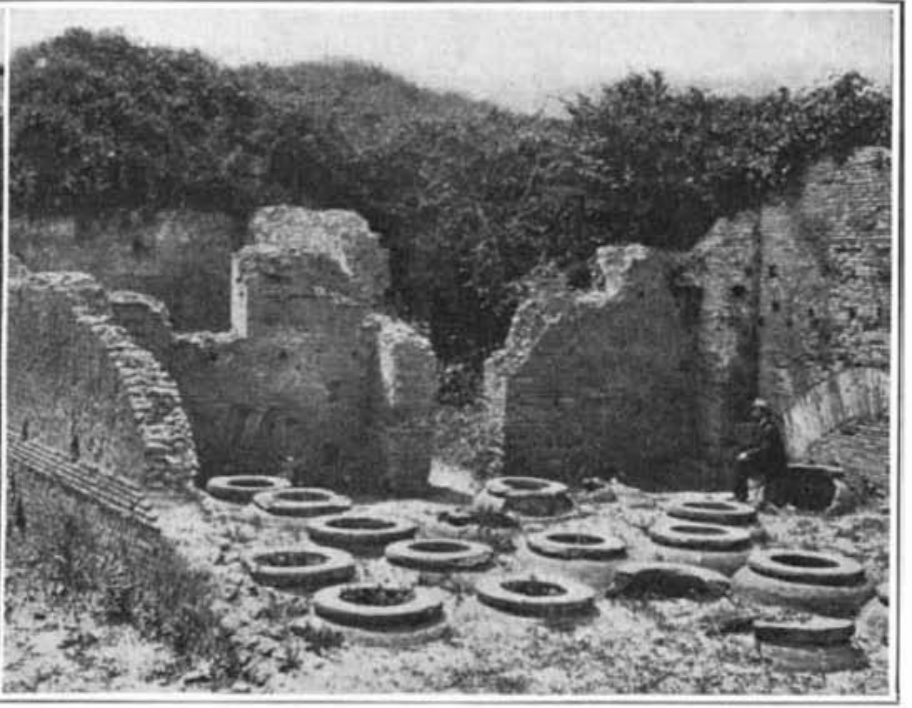

INTERIOR OF WAREHOUSE WITH BURIED AMPHORA FOR OIL, WINE, ETC. mile long. The breakwater was constructed with the aid of caissons. The huge ship by which the Vatican obelisk was brought from Egypt was filled with concrete until it sank, then it was strengthened with rocks until it was above the level of the sea, when it was crowned by a lighthouse.

"Porto," Trajan's harbor, is now two miles inland, and is a shallow lake surrounded by ruins. It resembled in every way a modern port: it was hexagonal in shape, and the basin communicated with the Port of Claudius. Trajan's harbor is cne of the most interesting works of Imperial Rome.

Egypt alone shipped 190,000,000 bushels of grain to Rome, and Sicils, Sardinia, and other places poured in their enormous supplies of foodstuffs. In addition to this mas be reckoned the vast quantities of building materials, especially marble, which were imported. The Claudian Harbor was also used as a great naval station, and here was also the central post office for foreign correspondence. In modern times harbors have been constructed on even a larger scale than the three harbors mentioned, which successively served to receive the great ocean-borne commerce of Rome; but none of them ever possessed the same magnificence.

We quote from Rodolfo Lanciani's "Ancient Rome in the Light of Recent Discoveries,"' as follows:

"The Claudian harbor was not only a commercial, but also a military station, from which emperors and admirals were wont to sail, escorted by powerful fleets on their expeditions, to the far-awas border lands of the empire. The same harbor contained a central post office for correspondence with the provinces bejond the sea, the existence of which office was revealed for the first time in 1874. Our late King Victor Emmanuel, when undertaking, near the end of that zear, some excavations on his hunting estate of Castel Porziano, between Ostia and Torre Paterno, discovered the public square or forum of a village, named Vicus Augustanus Laurentium, mentioned by Pling the jounger as adjoining his famous Laurentine villa. In the center of the square stood the marble pedestal of a statue, raised by the worthy inhabitants of the village in memory of a local benefactor named $\mathbf{P}$. Aelius Liberalis, a freedman of the Emperor Hadrian. As usual, the career of the gentleman so highly esteemed by his fellowcitizens is described in the legend on the pedestal. We are told by it how Liberalis began his career in the finance department as cashier of the branch office for the importation of breadstuffs, which had been established at Ostia as the landing place of the fleets laden with the harvest of all the provinces of the empire. In course of time he was elected to another office, procurator pugillationis et ad naves vagas'postmaster of Ostia and superintendent of despatch tsoats.'

${ }^{1}$ By permission of the publishers, Houghton, Mifflin \& Co.
"Postal institutions, in the modern sense of the word, were not unknown in Roman times. To secure quick and accurate intelligence, even from the remotest provinces, Augustus established, all along the great highways, a system of couriers mounted on swift horses, and stationed at an average distance of seven miles from one another.

"Later on he organized a regular service of mail coaches which seems to have been brought to a higher point of perfection by the Emperor Trajan. These accommodations, however, were reserved for the benefit of government emplojes-such as cabinet messengers, military officers, governors, and so onand very seldom were for the benefit of private individuals to whom the privilege of using mail coaches was granted only by the emperor himself, or by the governor of a province. At the same time all the burden of the institution had to be borne by the inhabitants of the villages and towns crossed or approached by the high road; thes were compelled to supply horses, mules, and oxen, and to keep the stations in proper repair; in other words, they had to pas all the expenses of an organization from which thes did not reap any advantage except the manure from the stables, graciously left them by the generosity of the government. Good, humane emperors did their best to relieve the populace from this indirect heavs taxation. There is a coin struck in honor of Nerva with a legend which signifies that the inhabitants of the peninsula at least had been exempted from compulsory supply of horses. Hadrian and Antonius seem to have met the exigencies of the service with their own purse; and, finally, Severus Alexander: transferred permanently the burden from the people to the imperial treasury. The postmaster-general, stigled 'praefectus vehiculorum,' of equestrian rank, was selected generally from among retired cavalry officers; he had under his orders provincial postmasters of inferior rank.

"Such was the state of things as regards the over-land post; regarding the maritime post nothing was known until the inscription of P. Aelius Liberalis was brought to light. His double office of postmaster and master of despatch boats makes it evident that the two things were connected as two branches of the same department. There is no doubt that the ncives vagae of the inscription were something like the naves tabellariae mentioned by Seneca as running in front of the fleet laden with grain from Egypt to announce its arrival at Pozzuoli, or like the naves speculatoriae, corresponding to the avisos of the modern navy. There is no doubt that, with the combined action of canvas and oars, finely-modeled ships could accomplish as quick a passage across the sea as was usually made in the first quarter of the last century. This is proved, to quote only one argument by the remarkable instance related by Plutarch, in chapter sixteen of his life of Cato, when 
to impress the Senate with the necessity 'delendae Carthaginis, he unfolded his mantle and showed the astonished assembly a batch of fresh figs which had been gathered on the African coast only two days before."

The harbor system at Ostia was brought to absolute perfection by Trajan. He was the builder of that magnificent inner lock, which, although left fully two miles inland by the filling up of the estuary, still exists in its integrity, and is known, especially among wild-duck shooters, as the Lago Trajano, the Lake of Trajan. It had the form of a regular hexagon, 393,000 square yards in extent, with a line of quays 2,156 yards long and with a constant depth of 18 feet. The construction of Trajan's dock require the excavation and removal of $85,000,000$ cubic feet of sand, and the construction of $1,940,000$ cubic feet of masonry.

Communication with the sea was of far greater importance to ancient than to modern Rome, and its former facility was one of the chief factors in the attainment of the proud rank held by the mistress of the world. The coast was a favorite resort of the wealthy Romans, as the numerous villas testify; but the deposits of mud and sand left by the Tiber, especially when in flood, have thrown forward the coast line and entirely altered its appearance. It is now desolate, and is skirted by a broad belt of forest (macchia), where the malaria in summer is endemic. Lofty sand-hills (tumoleti), extending to the south beyond the Pontine Marches, bound the whole coast.

Anzio, a favorite resort of the Romans during the bathing season (June, July and August), in spite of its liability to fever, occupies the site of the ancient Antium.

Antium, the capital of the Volsci, and a prosperous seaport at an early period, the place where Coriolanus sought refuge when banished from Rome in 490 B. C. and where he died after sparing Rome at the intercession of his mother, was compelled in 468 to succumb to the Romans. In 338, when all the Latins were conquered, Antium received a Roman colony, and was thus permanently united with Rome. Extensive villas were erected here toward the end of the republic. Cicero possessed an estate at Antium, the tranquillity and charms of which he highly extols. Caligula and Nero were born here; the latter constructed an artificial harbor. Though at a later period Antium seems to have been surpassed in popularity by Baiae and the places on the bay of Naples, the temple of Fortune, mentioned by Horace, where oracular responses were given, existed until the latest era of paganism. The place was entirely deserte in the middle ages, but in the 16th century it began to be rebuilt. The present town dates almost wholly from the period after the restoration of the harbor by Innocent XII. (1698).

The station lies close to the Piazza, and a few paces from the small harbor, which, as it opens to the south, is in continual danger of being sanded up. The remains of an ancient pier may be seen opposite in the direction of Nettuno, near the bathing establishment. Nero's harbor lay to the west of the present one; it was about 150 acres in area and was protected by a jetty of which traces are still visible above the water.

GREEK TEMPLE OF 400 B. C.

GREEK archaeologists have unearthe an imposing temple at Rerras, Thessaly. The structure is in an excellent state of preservation and is stated to be as laige as the temple of Jupiter at Olympia.

The bronze inscriptions establish the date as that of 400 B. C. Tablets have also been found bearing indications of laws and resolutions of ancient civilization. This is the second temple which has been discovere within a month, the first having been found near the city of Volo. The excavations are continuing.

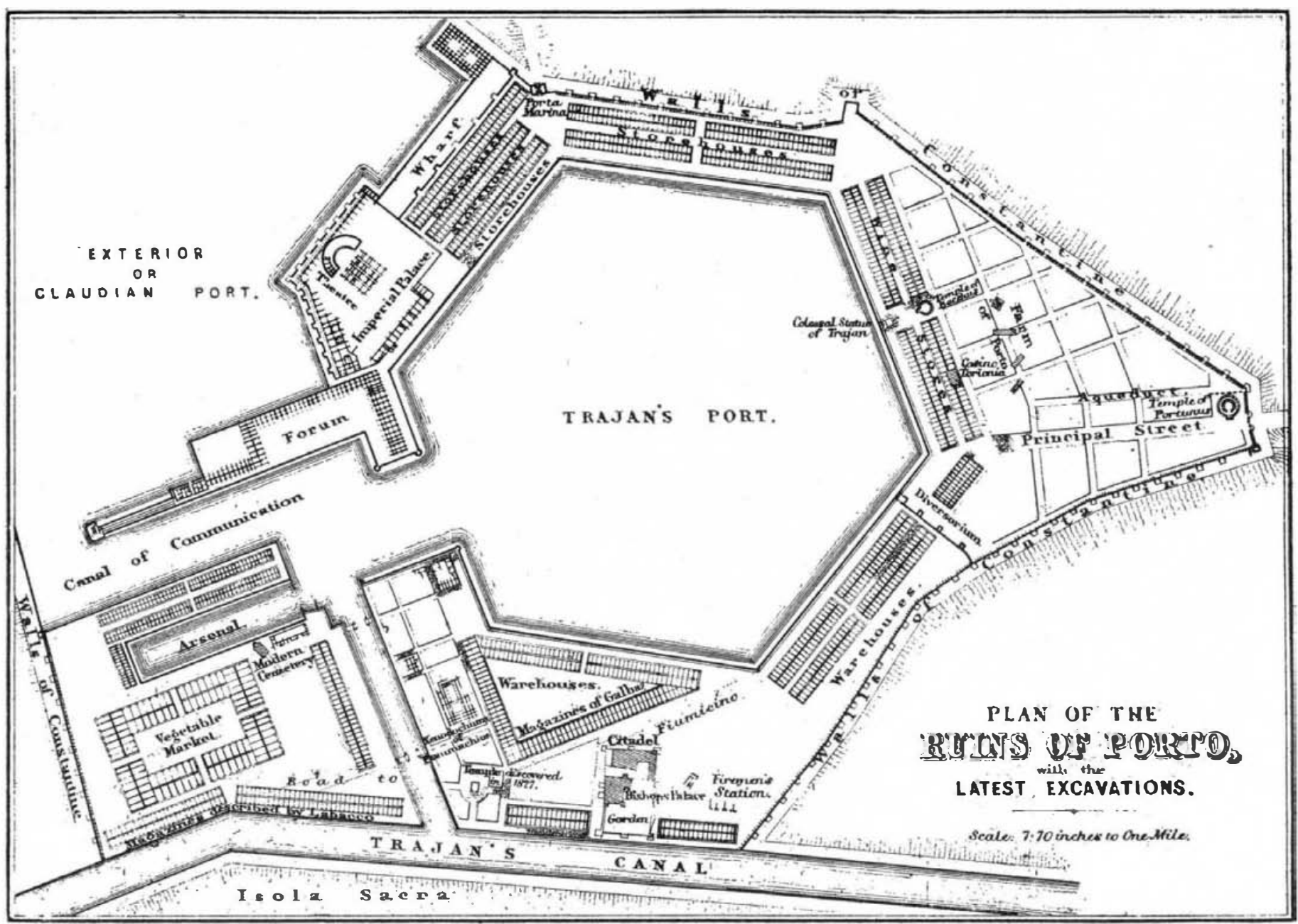

THE HEXAGONAL INNER HARBOR BUILT BY TRAJAN IN $103 \mathrm{~A} . \mathrm{D}$. 